\title{
DESAIN DAN PENGEMBANGAN APLIKASI SISTEM ADMINISTRASI DESA TEGALWERU KECAMATAN DAU
}

\author{
Paulus Lucky Tirma Irawan 1 , Yudhi Kurniawan², Windra Swastika ${ }^{3}$ \\ ${ }^{1,3}$ Program Studi Teknik Informatika, Fakultas Sains dan Teknologi \\ ${ }^{2}$ Program Studi Sistem Informasi, Fakultas Sains dan Teknologi \\ Universitas Ma Chung \\ Email: paulus.lucky@machung.ac.id
}

\begin{abstract}
Tegalweru is located in Dau, Malang. Tegalweru has 3 hamlets, including Krajan, Kraguman and Jengglong hamlet. In data management, Tegalweru is assisted by a number of village officials consisting of Kaur (Head of General Affairs), Finance Chief, Kebayan, Kuwono, Modin, Pramu, Kepetengan and Kamituwo. One routine administration that is directly related to community service is correspondence activities, such as making certificates starting from the domicile certificate, business domicile certificate, residence certificate, and others. Based on the initial analysis of the findings in the field, there are several potential problems found. The absence of a system makes the administrative routine management process less effective because population data that is the main supporting data must be accessed manually. This problem needs to get special attention so that Tegalweru can minimize the mistakes that occur due to the administrative process carried out manually services to the community so the service quality can be improved. An Information System has been made to help stake holders in doing their administrative services to the society.
\end{abstract}

Keywords: Application, Administration, Information System

\begin{abstract}
Abstrak. Desa Tegalweru terletak di Kecamatan Dau, Kabupaten Malang. Desa Tegalweru memiliki 3 dusun, meliputi dusun Krajan, dusun Kraguman dan dusun Jengglong. Dalam pengelolaan data masyarakatnya, Desa Tegalweru dibantu oleh beberapa perangkat desa terdiri dari Kaur (Kepala Urusan) Umum, Kaur Keuangan, Kebayan, Kuwono, Modin, Pramu, Kepetengan dan Kamituwo. Salah satu rutin administratif yang berkaitan langsung dengan layanan masyarakat adalah kegiatan surat menyurat, seperti pembuatan surat-surat keterangan mulai dari surat keterangan domisili, surat keterangan domisili usaha, surat keterangan kependudukan, dan lainnya. Berdasarkan analisa tahap awal terhadap data temuan dilapangan, terdapat beberapa potensi masalah yang ditemukan. Ketiadaan sistem membuat proses pengelolaan rutin administratif menjadi kurang efektif karena data kependudukan yang menjadi data pendukung utama harus diakses secara manual. Permasalahan ini perlu untuk mendapatkan perhatian khusus sehingga Desa Tegalweru dapat meminimalisir kesalahan-kesalahan yang terjadi diakibatkan oleh proses administrasi yang dilakukan secara manual sehingga layanan kepada masyarakat dapat ditingkatkan. Kegiatan pengabdian ini telah menghasilkan sebuah aplikasi sistem informasi administrasi berbasis web yang sudah dapat digunakan untuk membantu kantor desa Tegalweru dalam menjalankan kegiatan rutin administratif dan pengelolaan data kependudukan dengan lebih baik dan cepat.
\end{abstract}

Kata kunci: Aplikasi, Administrasi, Sistem Informasi

\section{PENDAHULUAN}

Desa Tegalweru terletak di Kecamatan

Dau, Kabupaten Malang. Desa dengan jumlah $1043 \mathrm{KK}$ ini memiliki jumlah penduduk kurang lebih 3573 orang (berdasarkan data kependudukan per September 2017). Desa Tegalweru memiliki 3 dusun, meliputi dusun Krajan, dusun Kraguman dan dusun Jengglong. Dari ketiganya, dusun Krajan memiliki luas area yang paling besar, sehingga dalam pengelolaannya wilayah Krajan dibagi lagi ke dalam 3 wilayah yang lebih kecil, mulai dari dusun Krajan wilayah 1, dusun Krajan wilayah 2 dan dusun Krajan wilayah 3. Pada tabel 1.1 hingga 1.5 dapat dilihat detil data kependudukan yang ada di desa Tegalweru. Berdasarkan peta Desa Tegalweru (Lampiran A) diketahui hampir sebagian besar wilayah desa ini masih berupa ladang disusul sawah dan daerah pemukiman. Kantor Desa Tegalweru terletak di jalan Brawijaya no. 90, Desa Tegalweru, 65151.

Dalam pengelolaan data masyarakatnya, Desa Tegalweru dibantu oleh beberapa perangkat desa terdiri dari Kaur (Kepala Urusan) Umum, 
Kaur Keuangan, Kebayan, Kuwono, Modin, Pramu, Kepetengan dan Kamituwo. Masingmasing perangkat memiliki tugas pokoknya masing-masing yang sudah lebih dulu diatur di dalam Undang-undang 32 Tahun 2004 tentang Pemerintahan Desa pasal 209 ayat 1. Diantara perangkat-perangkat tadi, kegiatan administratif desa lebih sering melibatkan perangkat Kebayan dan Modin. Perangkat Kebayan memiliki tugas pokok dibidang administrasi kependudukan, adminsitrasi pertanahan, urusan transmigrasi dan monografi desa. Sementara Modin salah satu tugas pokoknya adalah mengadakan pencatatan pengurusan kematian termasuk segala sesuatu yang berkaitan dengan permasalahan kematian tersebut, serta pendataan tentang nikah talak rujuk.

Salah satu rutin administratif yang berkaitan langsung dengan layanan masyarakat adalah kegiatan surat menyurat, seperti pembuatan surat-surat keterangan mulai dari surat keterangan domisili, surat keterangan domisili usaha, surat keterangan kependudukan, surat keterangan SPPT, surat keterangan kehilangan, surat keterangan tidak mampu, surat keterangan bepergian, surat keterangan bepergian atau lebih dikenal boro kerja, surat permohonan bantuan umum, surat permohonan bantuan pembangunan, surat rekomendasi, surat keputusan, surat kuasa, surat undangan sidang tanah, serta surat-surat keterangan untuk kasuskasus khusus lainnya. Hasil temuan di lapangan, rutin administratif ini dalam pelaksanaannya hanya ditangani oleh seorang perangkat saja (Kebayan) sehingga tidak jarang proses pembuatan surat cukup memakan waktu. Belum lagi dalam pelaksanaannya, surat-surat yang sudah diregister hanya diarsip secara manual menggunakan file excel dan buku catatan (log book). Hingga saat ini Desa Tegalweru belum menggunakan aplikasi sistem informasi yang secara khusus digunakan untuk membantu proses pengelolaan rutin administratif.

Berdasarkan analisa tahap awal terhadap data temuan dilapangan terkait dengan rutin admisnitratif di Desa Tegalweru, terdapat beberapa potensi masalah yang ditemukan. Ketiadaan sistem memuat proses pengelolaan rutin administratif menjadi kurang efektif karena data kependudukan yang menjadi data pendukung utama harus diakses secara manual. Proses pengerjaan yang hanya terfokus pada perangkat Kebayan (satu orang) membuat layanan masyarakat tidak jarang mengalami kendala ketika perangkat Kebayan berhalangan sehingga tidak dapat memenuhi kewajibannya, padahal permohonan surat cukup sering diterima (5-10 permohonan per harinya). Potensi permasalahan berikutnya, proses pengarsipan data teregister yang masih mengandalkan file excel dan buku log book sering kali berdampak pada proses pembuatan laporan rutin administratif yang sering tidak sesuai karena kesalahan pencatatan (lupa tercatat atau tercatat lebih dari sekali). Belum lagi jika dalam suatu waktu akan dilakukan penelusuran rekam jejak terhadap suatu surat yang pastinya akan memakan waktu yang cukup lama. Potensipotensi masalah ini perlu untuk mendapatkan perhatian khusus sehingga Desa Tegalweru dapat meminimalisir kesalahan-kesalahan yang sering dialami serta meningkatkan layanannya kepada masyarakat.

\section{METODE PELAKSANAAN}

Metode pelaksanaan kegiatan pengabdian kepada masyarakat ini dilakukan dalam beberapa tahapan menggunakan beberapa jenis metode yang disesuaikan dengan kondisi dilapangan. Kegiatan diawali dengan tahapan analisa kebutuhan. Pada tahapan ini dilakukan pengumpulan data terhadap segala sesuatu yang berhubungan dengan kegiatan rutin administratif terutama untuk modul data kependudukan di Desa Tegalweru. Proses pengumpulan data dilakukan menggunakan teknik wawancara dan pengumpulan data-data fisik ke perangkat desa terkait, yakni Kebayan dan Modin.

Setelah data-data terkumpul, barulah dilakukan pembahasan terhadap beberapa usulan yang dapat menjadi alternatif untuk menyelesaikan permasalahan yang ada. Pada kegiatan pengabdian ini, kemudian dirancang sebuah aplikasi sistem informasi berbasis web untuk memudahkan perangkat Desa dalam melakukan kegiatan rutin administratif yang menjadi fokus layanan utama dari kantor desa tersebut. Sistem informasi administrasi yang 
dirancang nantinya akan bertindak sebagai antarmuka untuk mendapatkan informasi data kependudukan, serta informasi administrasi surat masuk dan surat keluar termasuk di dalamnya panduan untuk mencetak surat-surat yang terlibat di dalam kegiatan rutin administratif desa Tegalweru.

Setelah melewati tahapan desain sistem aplikasi, kegiatan dilanjutkan dengan mengimplementasikan desain-desain yang ada ke dalam sebuah purwarupa aplikasi berbasis web yang sudah terintegrasi dengan basis data. Proses pengembangan dan pengujian dilakukan hampir berbarengan untuk memastikan setiap modul (modul testing) yang terlibat benar-benar dapat bekerja dengan baik sebelum dilakukan pengujian secara menyeluruh terhadap sistem yang dibangun (integration testing). Tahapan pengujian juga akan melewati fase pengujian dilingkup pengembang (alpha testing) serta tahapan pengujian yang melibatkan pengguna akhir (beta testing). Barulah setelah proses pengujian selesai dilakukan, proses pelatihan penggunaan aplikasi diberikan. Pada tahapan ini diharapkan kesalahan sistem yang terjadi sudah diminimalisir sekecil mungkin.

Hasil seluruh rangkaian kegiatan yang sudah dilakukan kemudian akan didokumentasikan secara lengkap untuk kemudian dibuatkan laporan final serta persiapan pendaftaran hak cipta aplikasi. Oleh karena pendaftaran hak cipta aplikasi ini membutuhkan dokumentasi lengkap penggunaan aplikasi sehingga sistem aplikasi yang dikembangkan harus dipastikan dapat berjalan dengan baik terlebih dahulu.

\section{HASIL DAN PEMBAHASAN}

UU 6 Tahun 2014 tentang Desa mengamanatkan pemerintah daerah wajib mengembangkan sistem informasi desa sistem informasi desa dan pembangunan kawasan perdesaan. Sistem informasi desa meliputi data desa, data pembangunan desa, kawasan perdesaan, serta informasi lain yang berkaitan. Data tersebut dikelola oleh pemerintah desa dan dapat diakses oleh masyarakat desa serta semua pemangku kepentingan. Kegiatan pengabdian masyarakat ini akan menghasilkan sebuah aplikasi sistem informasi layanan administrasi desa. Aplikasi ini dapat menjadi solusi terhadap potensi permasalahan yang telah dikemukakan sebelumnya. Pembuatan aplikasi yang sistematis dapat mengurangi faktor kesalahan manusia (human error) yang terjadi selama ini. Lingkungan aplikasi yang user friendly dapat memudahkan proses pembuatan surat. Dengan adanya aplikasi ini, rutin administratif yang mulanya hanya ditangani oleh seorang saja dapat dijalankan oleh siapa saja yang memiliki akses. Aplikasi sistematis juga akan memudahkan ketika Desa Tegalweru hendak melakukan penelusuran rekam jejak atau hendak menghasilkan laporan rekapitulasi yang diperlukan. Hasil analisa tahap awal terhadap potensi permasalahan yang muncul adalah keterbatasan tenaga dalam pengelolaan rutin administratif serta ketiadaan sistem yang secara khusus ditujukan untuk membantu rutin administratif tersebut.

Menilik kegiatan rutin administratif adalah layanan yang paling sering dibutuhkan oleh masyarakat, pembuatan sistem berbasis IT dirasa perlu dilakukan untuk mengatasi akar permasalahan yang ada sehingga Desa Tegalweru dapat meningkatkan produktifitasnya dalam memberikan layanan masyarakat. Kegiatan rutin administratif ini juga memberikan pengaruh terhadap keterkinian data kependudukan yang ada di Desa. Dengan adanya aplikasi yang sistematis, data kependudukan, laporan rekapitulasi yang harus dihasilkan setiap masa periode waktu tertentu dapat diketahui dengan cepat dan tepat.

\section{Fitur Aplikasi yang Sudah Dirancang}

Bagian ini menjelaskan secara rinci fitur aplikasi yang sudah dirancang dan dikembangkan pada kegiatan pengabdian kepada masyarakat di desa Tegalweru.

\section{Fitur User Login}

Fitur User Login mengatur akses pengguna terhadap aplikasi sistem informasi administrasi Desa tegalweru. Pembagian tingkatan akses pada aplikasi ini masih dibagi ke 
dalam 3 tingkatan pengguna, yakni superadmin, kepala desa, dan admin.

\section{Fitur Manajemen password}

Fitur manajemen password memudahkan pengguna untuk melakukan proses penggantian sandi yang akan digunakan untuk masuk ke dalam aplikasi sistem informasi. Fitur ini disamping memberikan kemudahan kepada para penggunanya untuk melakukan penggantian password juga dapat memudahkan pengguna untuk melakukan proses recovery password jika terjadi kelalaian pengguna (lupa password).
3. Fitur Manajemen Data Grafik Kegiatan Administratif Desa

Fitur ini memudahkan pengguna (admin \& Kepala Desa) untuk mendapatkan gambaran besar maupun gambaran detil terhadap kegiatan administratif yang sudah terjadi atau kegiatan administratif yang sedang berjalan pada periode waktu tertentu. Manajemen Data Grafik sangat diperlukan untuk menyusun laporan rekapitulasi pelaksanaan kegiatan administratif desa yang dilakukan secara berkalan (setiap bulan dan setiap tahun).

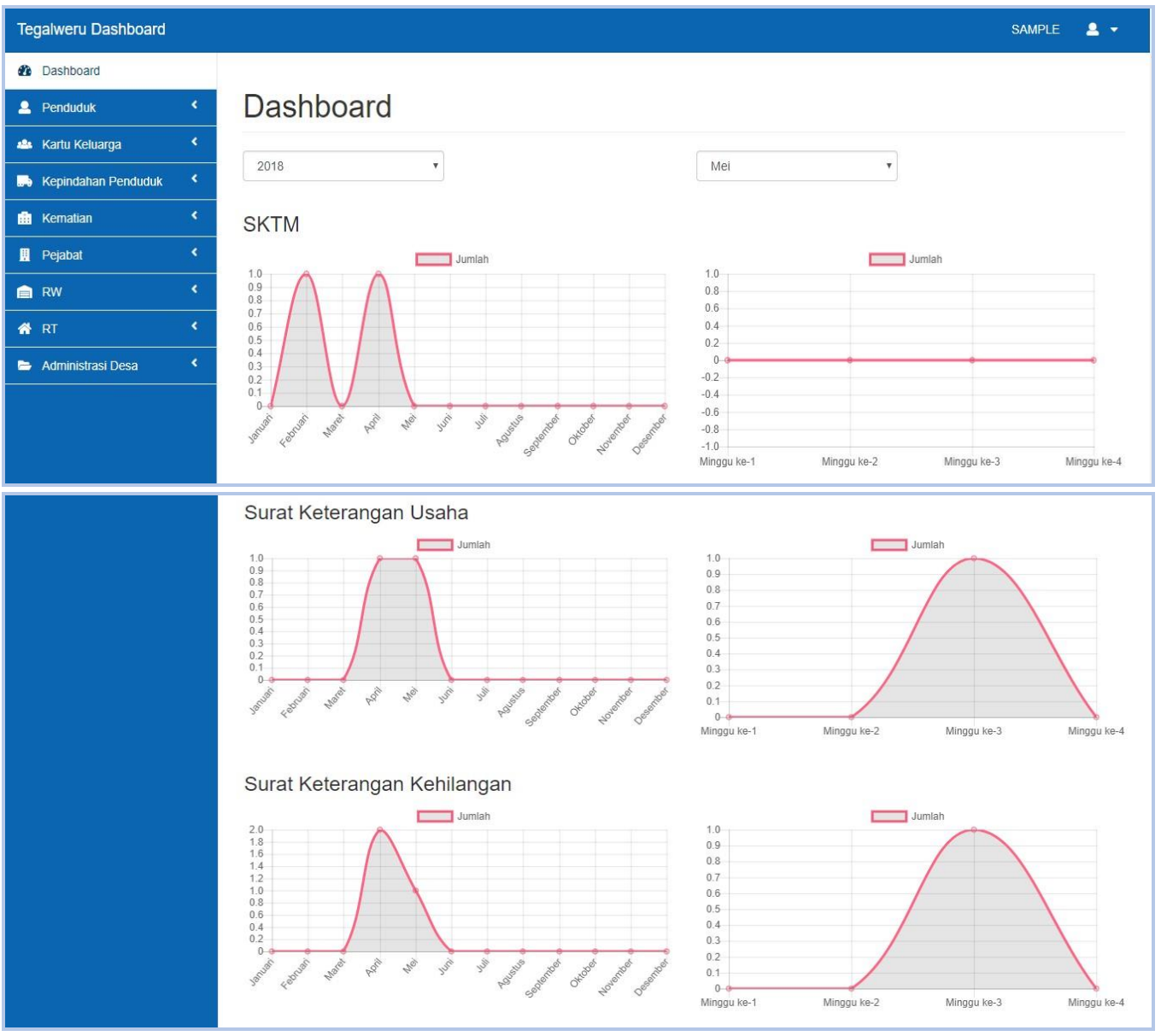

Gambar 1. Laman Manajemen Data Grafik

\section{Menu Penduduk}

Pada menu penduduk, pengguna dapat melakukan beberapa aksi yang terkait dengan data penduduk, antara lain:

- Melakukan pencarian data penduduk pada sub menu Data Penduduk melalui masukan kategori yang telah disediakan.

- Menampilkan sekaligus melakukan penyuntingan detail data penduduk dan detail data Kartu Keluarga (KK) melalui masukan data nomor NIK dan nomor KK pada sub menu Data Penduduk.

- Melakukan pengunduhan data penduduk dalam format pdf (.pdf) pada sub menu Data Penuduk.

- Menampilkan statistik data penduduk dalam bentuk diagram pada sub menu Statistik Data Penduduk. 


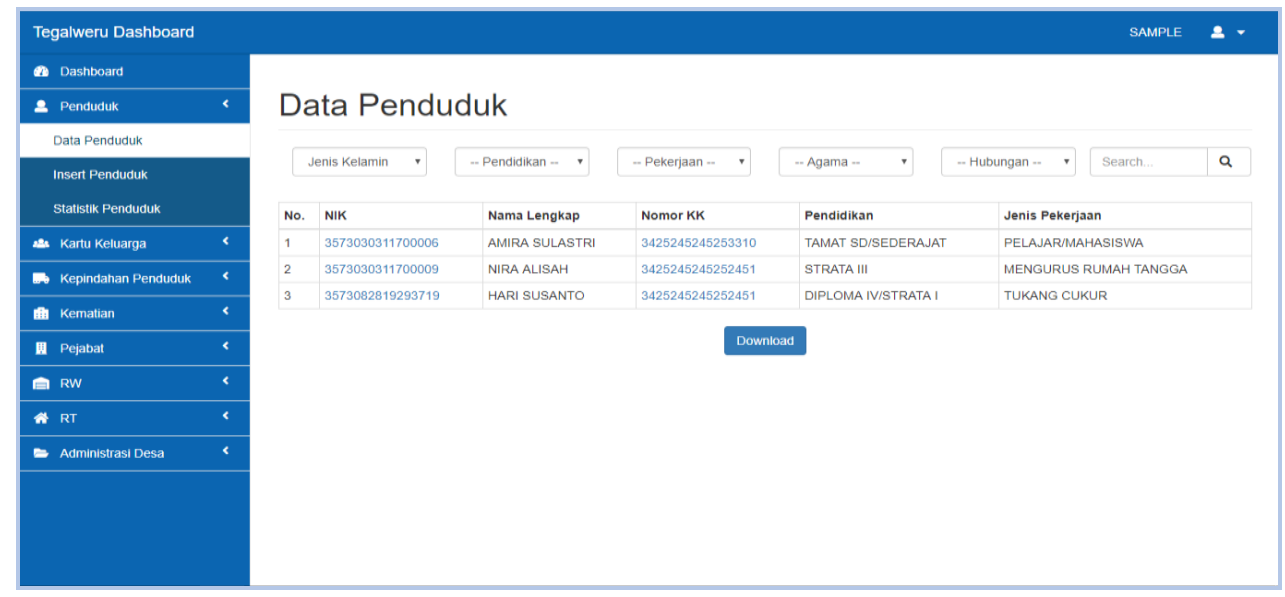

Gambar 2. Laman Manajemen Data Penduduk

\section{Menu Kartu Keluarga}

Pada menu kartu keluarga, pengguna dapat melakukan beberapa aksi yang terkait dengan data kartu keluarga, antara lain:

- Melakukan pencarian data kartu keluarga pada sub menu Data Kartu Keluarga dengan melakukan penyaringan dari data masukan kategori RT dan RW.

- Menampilkan sekaligus melakukan penyuntingan terhadap detail data kartu keluarga dan detail data penduduk melalui masukan data nomor KK, dan NIK kepala keluarga jika terjadi kesalahan data pada sub menu Data KK.

- Menampilkan statistik data kartu keluarga dalam bentuk diagram pada sub menu Statistik KK.

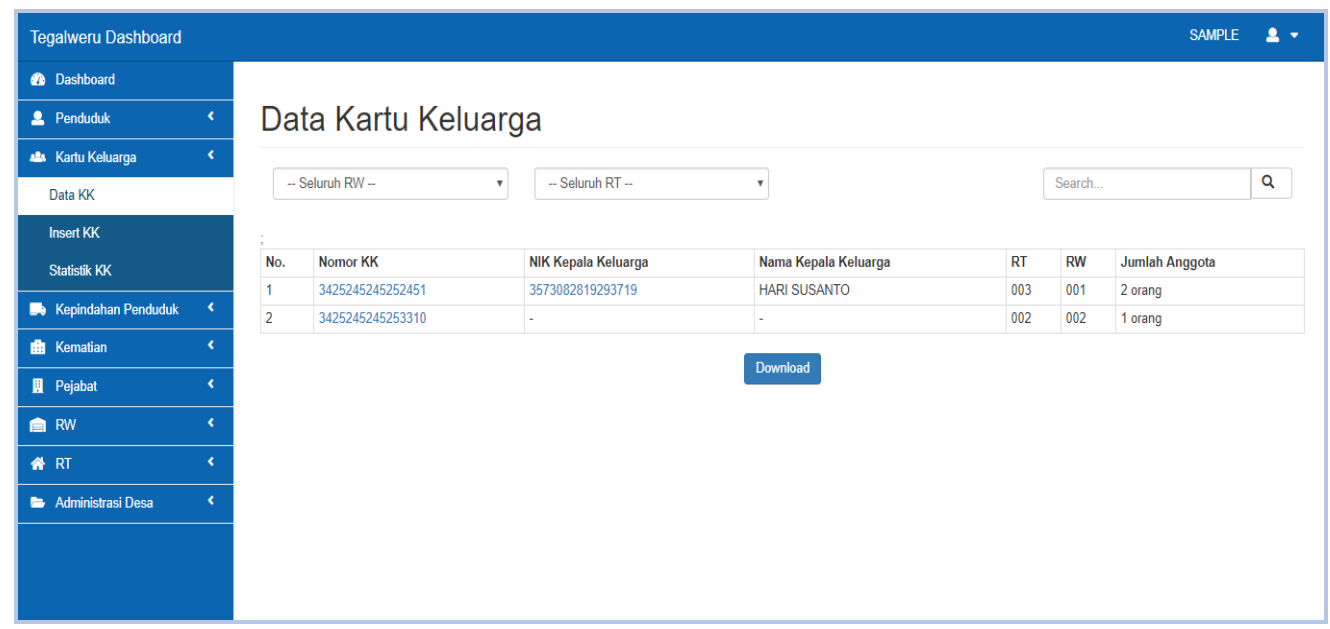

Gambar 3. Laman Manajemen Data Kartu Keluarga

\section{Menu Kepindahan Penduduk}

Pada menu kepindahan penduduk, pengguna dapat melakukan beberapa aksi yang terkait dengan data kepindahan penduduk, antara lain:

- Melakukan pencarian data kepindahan penduduk melalui masukan data kategori tahun dan bulan pada sub menu Data Kepindahan.

- Menampilkan dan melakukan penyuntingan data detail penduduk melalui masukan data nomor NIK. 
- Melakukan penyuntingan atau penghapusan data pindah domisili pada sub menu Data Kepindahan.
- Melakukan input data pindah domisili pada sub menu Insert Data Pindah

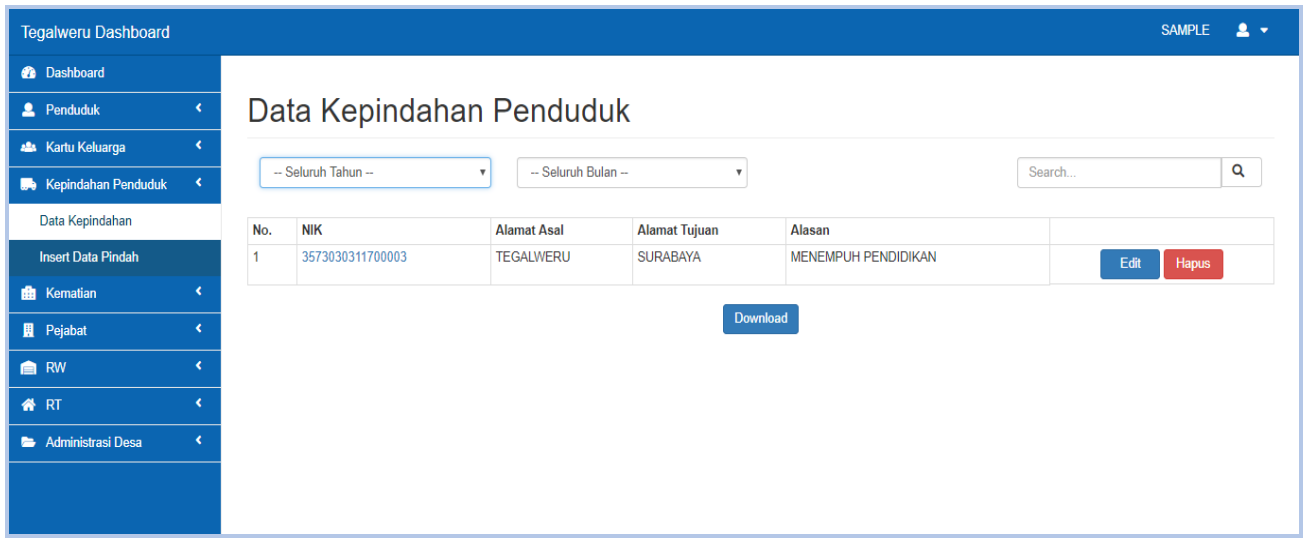

Gambar 4. Laman Manajemen Pindah Penduduk

\section{Menu Kematian}

Pada menu kematian, pengguna dapat melakukan beberapa aksi yang terkait dengan data kematian penduduk, antara lain:

- Menampilkan dan melakukan penyuntingan data detail penduduk melalui masukan data nomor NIK pada sub menu Data Kematian.
- Melakukan penyuntingan dan penghapusan data kematian penduduk pada sub menu Data Kematian.

- Mengunduh data kematian penduduk dalam format pdf (.pdf) pada sub menu Data Kematian.

- Melakukan input data kematian baru.

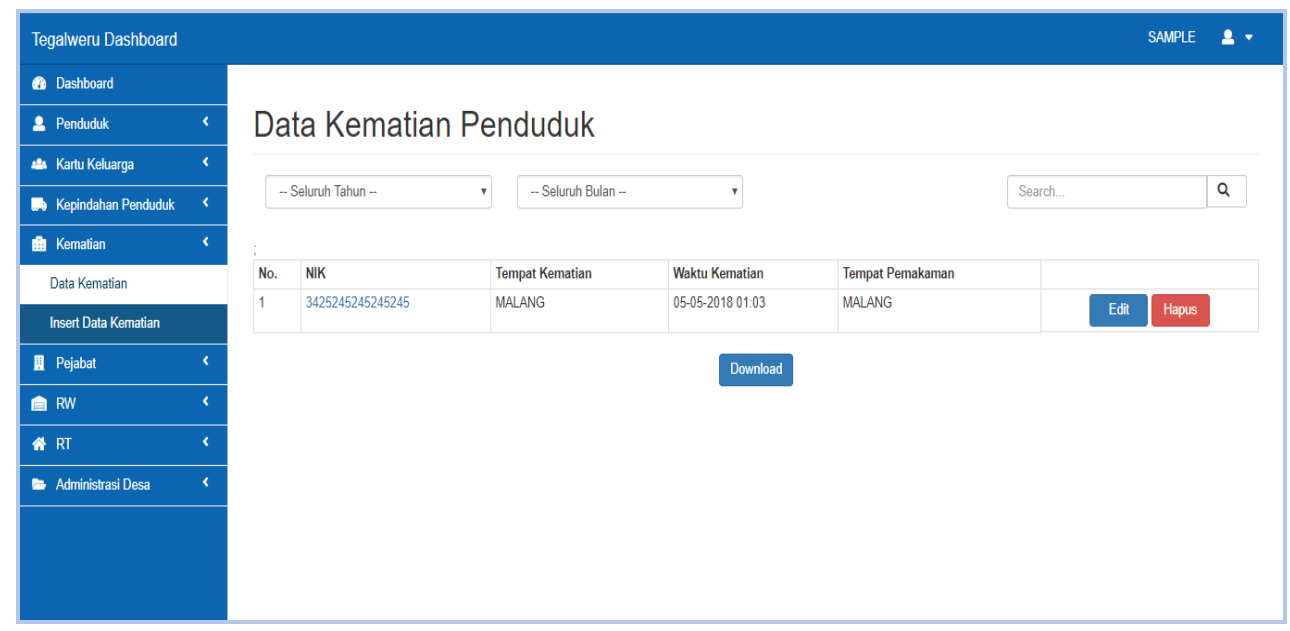

Gambar 5. Laman Manajemen Data Kematian

\section{Pejabat}

Pada menu Pejabat, pengguna dapat melakukan beberapa aksi yang terkait dengan data pejabat desa, antara lain:

- Melakukan penyuntingan dan penghapusan data pejabat desa.

- Melakukan input data pejabat desa baru.
Pada menu Rukun Warga, pengguna dapat melakukan beberapa aksi yang terkait dengan data penduduk, antara lain:

- Melakukan penyuntingan dan penghapusan data Rukun Warga

- Melakukan input data Rukun Warga baru. 
Pada menu Rukun Tetangga, pengguna dapat melakukan beberapa aksi yang terkait dengan data rukun tetangga, antara lain:

- Melakukan penyuntingan dan penghapusan data Rukun Tetangga

- Melakukan input data Rukun Tetangga baru.

\section{Administrasi Desa (Surat Keterangan)}

Pada menu administrasi desa, pengguna dapat melakukan beberapa aksi yang terkait dengan data administratif. Menu yang merupakan fitur utama aplikasi ini dirancang untuk dapat menghasilkan beberapa surat yang menjadi rutin adminsitratif desa, meliputi SKTM, SK Usaha,
SK Kehilangan, SK Lahir, SK Dukun, SK Wali Nikah, SK Pelunasan PBB, serta SKKB. Pada menu ini, pengguna dapat melakukan beberapa aksi seperti:

- Melakukan pencarian data SK dengan memfilter pada kategori tahun dan bulan.

- Pengguna bisa memilih untuk menampilkan, melakukan penyuntingan, dan mengunduh data detail SK secara perorangan maupun keseluruhan dalam format pdf (.pdf) pada sub menu Data SK.

- menambahkan data SK baru.

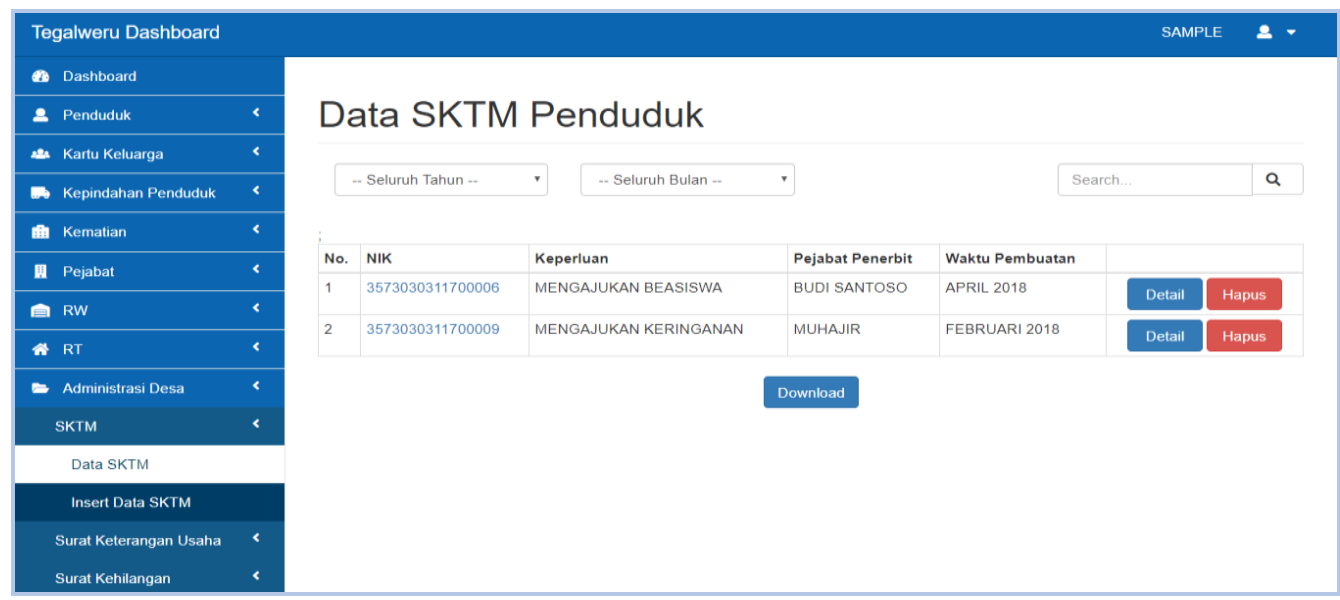

Gambar 6. Laman Administrasi SKTM

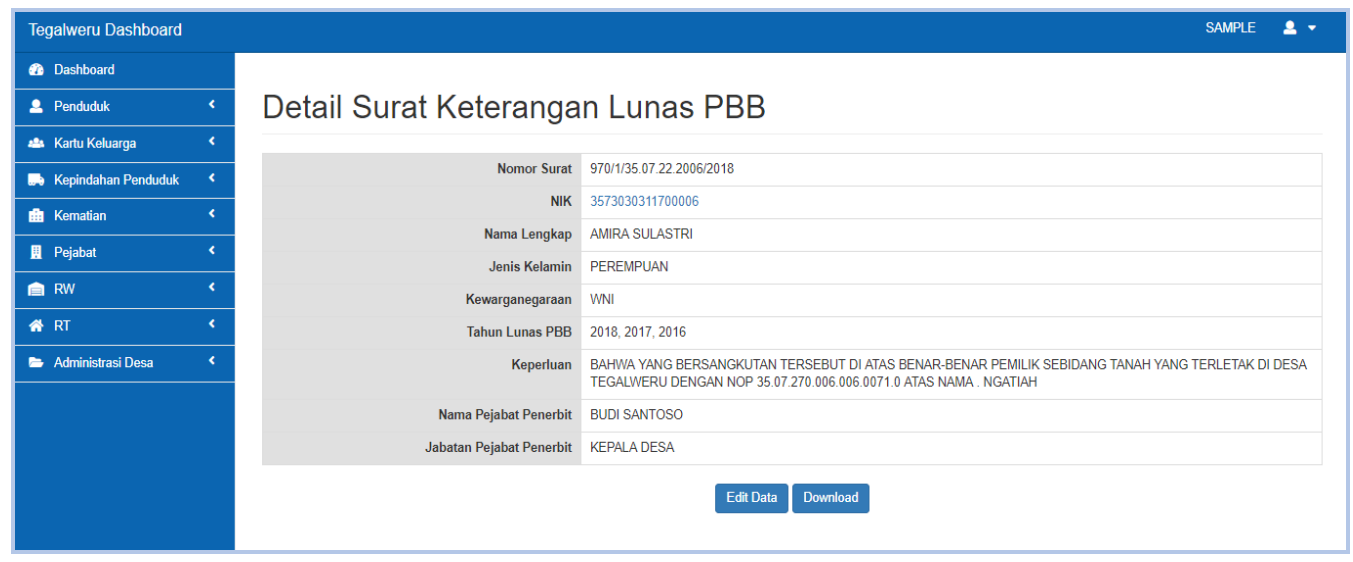

Gambar 7. Laman Administrasi Pelunasan PBB

Perancangan aplikasi tentunya bukan solusi yang terbaik jika tidak dilengkapi dengan pembekalan materi yang cukup kepada para perangkat desa yang akan mengoperasikan aplikasi yang dimaksud. sehingga pada akhir kegiatan pengabdian masyarakat ini diselenggarakan pelatihan dan pembinaan terhadap penggunaan aplikasi pada Januari 2018 (gambar 8). 


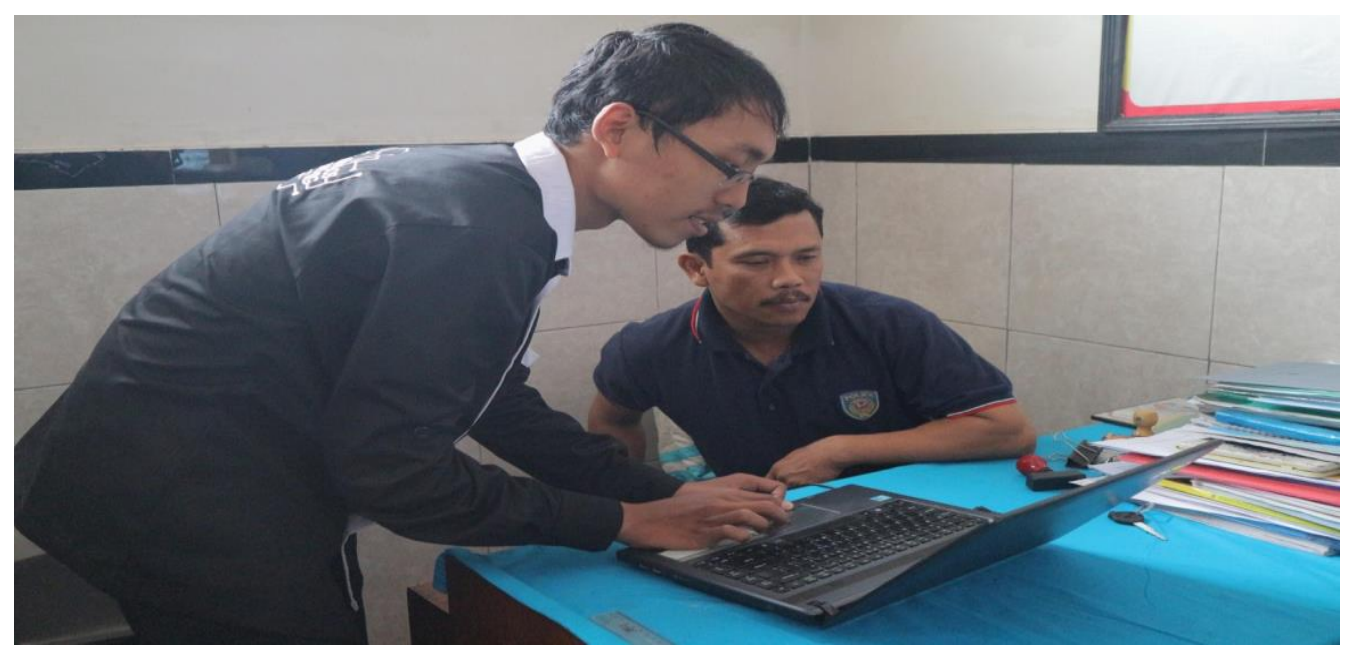

Gambar 8. Pelatihan Kepada Perangkat Desa

\section{SIMPULAN DAN SARAN}

Adapun kesimpulan yang didapatkan dari pelaksanaan kegiatan pengabdian kepada masyarakat ini, antara lain:

1. Aplikasi Sistem Informasi Administrasi Desa yang dirancang dan dikembangkan sudah dapat berfungsi sesuai dengan spesifikasi yang diharapkan. Desain aplikasi yang dirancang juga sudah sesuai dengan proses bisnis yang ada di desa Tegalweru sehingga dapat langsung diterapkan tanpa harus menambah ataupun merubah standar operasional prosedur yang sudah ada sebelumnya.

2. Layanan administrasi desa Tegalweru kepada masyarakat mengalami peningkatan yang baik terutama dari sisi dokumentasi dan rekapitulasi data surat masuk dan surat keluar, serta mendapatkan tanggapan yang positif dari perangkat dan masyarakat desa setempat.

\section{UCAPAN TERIMAKASIH}

Ucapan terima kasih terutama ditujukan kepada Lembaga Penelitian dan Pengabdian Kepada Masyarakat (LPPM) Universitas Ma Chung Malang sebagai pemberi dana kegiatan pengabdian kepada masyarakat ini.

\section{DAFTAR PUSTAKA}

Undang-undang 32 Tahun 2004 tentang

Pemerintahan Desa pasal 209 ayat 1

Undang-undang No 6 Tahun 2014 tentang

Pemerintahan Desa 